Historic, archived document

Do not assume content reflects current scientific knowledge, policies, or practices. 



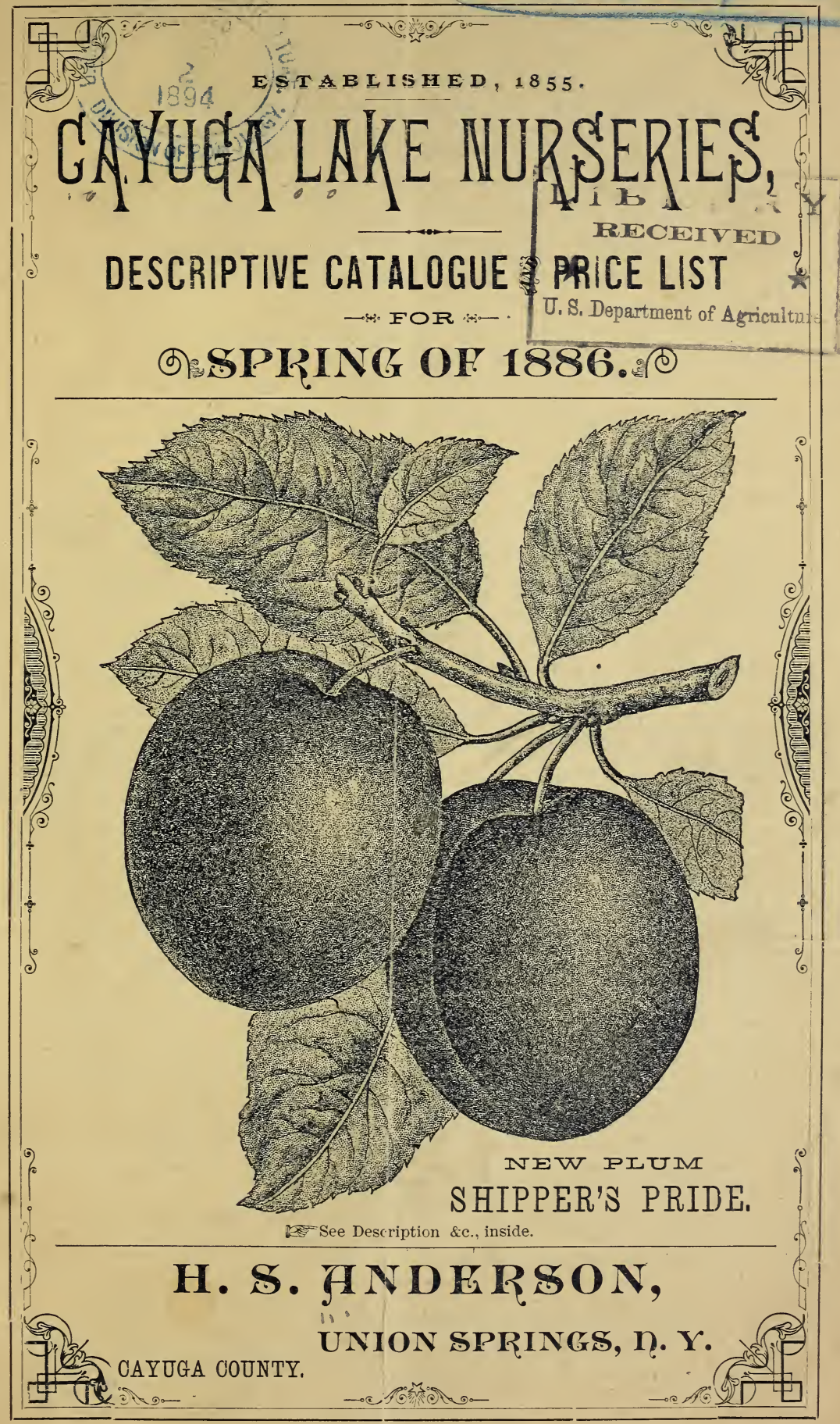

Enapp, Peck \& T romson, Printers, Auburb, N. . 


\section{CONDITIONS OF SALE, ETC.}

\section{PLEASE READ CAREFULLY BEFORE ORDERING.}

TERMS, CASH with order, or before shipment, unless by special agreement.

No Groods sent C. O. D. unless amounting to \$5 or more, and accompanied by one-half amount of order.

A Discount of 10 per cent. on all orders (at list rates accompanied with the cash before March 15, ) except Jewell, Ontario, Woodruff Red, Empire State and Niagara, which are Nett.

Remittances should be made by draft on New York City, Postal or Express money order on Union Springs, N. Y, or by registered letter at my risk.

Prices herein annul all previous quotations, and are for the quantities named, but six of a kind may be ordered at dozen rates, 50 at 100 rates, 500 at 1000 rates. Parties wishing larger quantities than those named are requested to correspond for special rates, as I grow stock in large quantities, I am prepared to offer special inducements on large orders.

Parties receiving this Catalngue, who have no nse for it, or who receive more than one copy, will confer a favor by handing it to some one who is interested in fruit culture, \&c.;

No charge for careful packing and delivering at express office, railroad station, or steamboat dock, after which goods are at the risk of the purchaser.

Stock Pacleed to go any Distance in 'Good Order.-Orders for small fruits and other light stock in small quantities, can be packed to go any distance by mail, and this will be found very convenient for parties living at a distance from railroad station or express office. Rates of postage are given under the different headings.

I would particularly request, that orders be sent in at as early a date as possible, thus insuring a better selectiou, as later in the season some varieties ordered are oftentimes exhausted; in such cases I will select sorts as near like those ordered as possible, unless requested not to do so. But if unible to fill any item in orders received before the packing season commences parties ordering will be notified at once that they may make other selections themselves.

My Stock is young, strong, well-grown, and I think will be found SECOND TO NONE. Especial pains has been taken to keep it PURE. and all varieties will be carefully labeled TRUE To NAME. Mistakes will sometimes occur in spite of all precautions, and I desire to be informed of such at once that all may be made right.

I offer in this list what I have a fair stock of, on my grounds, and of many of the leading and newer sorts I have a very large and well-grown stock. I have many varieties not named in this list that I can supply at low rates, and I offer all my stock as low as is consistent with genuine plants of good quality.

I have one of the finest assortments of Small Frnit Plants, Grape Vines, Apple, Pear, Plnm. Cherry and Peach Trees, Ornamental Trees and Shrubs, Climbing Vines, Ever greens, Roses, Bulbs, \&c.. that I have ever grown, and would call particnlar atiention to the attractive list of novelties offered herein. In addition to these I am testing many other new sorts but only such as are found worthy will be offered for sale.

Shipping Facilities.-Union Springs is on the Caruga Livision of the Geneva, Ithaca \& Sayre Railroad, (branch of the Lehigh Valley Railroad, ) by which road I have direct connection with the N. Y. C. \& H. R. R. R., both of which give me unsurpassed facilities for prompt, cheap and safe shipment North, Sonth and East, and to all points in the West and South-west by connecting fast freight lines, without incurring the extra transfer charges, of expensive forwarding agencies. For light packages I advise shipping by Express when it is cheaper than by mail, and can ship by either United States or American to all leading points in the United States and Canada.

Shipping Directions should be plainly and fully voritten, stating if goods are to be sent by freight, express or inail, and above all be sareful to sign your name. giving Post Office, Court, and State, and express or freight office to which good - are to be sent. When no directions are given, I forward by what I consider the best route, but will not be responsible for any errors or delays which may occur in this way. I would, however, advise shipment of all large orders, except Strawberry Plants, by fast freight, as that is much cheaper than express.

I had the past season, in specimen beds for testing, over two hundred and fifty varieties of Strawberries, thirty-five varieties of Raspberries, fifteen varieties of Blackberries, twelve varieties of Currants, ten varieties of Gooseberries, forty varieties of Grapes, as well as some of the larger New Fruits, inclading Champion and Rea's Mammoth Quince, Kieffer's Hybrid, President Drouard, Souvenir du Congress Pears.

I have endeavored to describe briefly and impartially only such varieties as have proved to be adapted to a wide extent of country and to varions soils and situations.

Thanlsing you for past favors, and assuring you that I shall endeavor by giving my personal at tention to all orders, to merit a coutinuance of the same, I am

Respectfully yours,

H. S. ANDERSON, Union Springs, N. Y.

Cayuga Lake Nurseries, Jarch 1st, 1886.

\section{The Planet Jr. Farm and Garden Implements.}

This is the most complete and popular line of goods we have ever sold. They are admirable in design, workmanship, material and finish. A Complete Deseriptive Catalogue illustrated with 40 engravings showing the tools at work. and containing practical instruction in the cultivation of garden and and field crops, will be mailed free on application. See $3 d$ page of cover for description. 


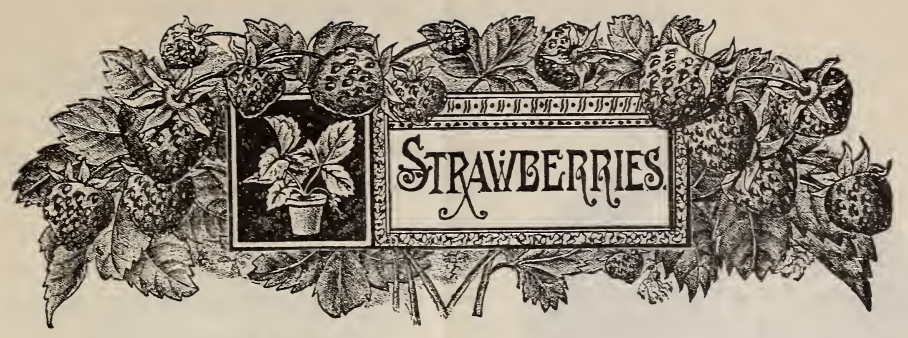

Planting and Culture.-For garden culture, rows should be $21 / 2$ feet apart, and plants set 12 to 15 inches apart in the rows. For field culture, rows should be 3 to $31 / 2$ feet apart. Spade or plow the ground deep, enrich well, and give thorough cultivation, and for best results keep in narrow rows with runners well cut. Mulch we late in the fall, and uncover crowns early in spring. After fruiting remove mulch and spade in, well rotted manure. Renew beds every third or fourth year.

Varieties marked (P) are pistilate, and should have some perfect flowered sort planted near them.

Plants will be mailed post paid, at the dozen rates- 15 cents per $50 ; 25$ cents per 100 in addition to regular rates.

Cornelia. (P) - A strong, healthy grower, blossoms late, and is less liable to injury from spring frosts; fruit very firm, good color, very regular in shape. It is of large size, productive, and I think will prove a decided acquisition as a LATE MARKET variety, as it is claimed to be the latest in season, yet introduced. 50 cents per dozen:

Ontario.-The introducer of this new berry claims for his favorite that it is a strong grower, has a perfect blossom, is of very large size, of superior quality, and very productive; season, medium early. Has not fruited with me. $\$ 2.00$ per dozen; SI0.00 per 100.

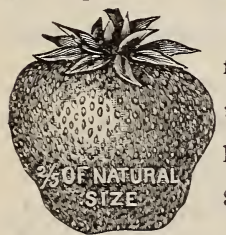

Jewell. (P) - A new berry of great promise. Originated from seed of Jersey Queen, and said to have all of the good qualities of its parent, and to surpass it in many particulars. It is of largest size and very productive. Has not fruited with me yet. $\$ 2.00$ per doz. ; \$1 2.00 per 100 .

May King.-A strong, healthy grower, berries being of large size, bright red and very productive. Not fruited here, but seems to be a good grower. 50 cents der dozen. $\$ 2.00$ per 100 .

Henderson.- This NEW STRAWBERRY originated in Connecticut, it is described by the introducers as follows: "The fruit is of the largest size, early, and immensely productive, but its excelling merit is in its exquisite flavor.

Whether for family or market use, the Henderson, is certain to become a popular sort ; and its strong and healthy growth will adapt it to almost every soil. It is what is known as a perfect flowered variety, and therefore will never fail to produce a crop." It has fruited with me, and the fruit is of fine quality. \$1.00 per dozen.

Old Iron-Clad.-(Phelps.) One of the earliest to ripen ; plant a strong healthy grower, very product:ve, berries large, very firm, and of good quality. A splendid market variety, resembles Wilson somewhat, but less acid in flavor. 50 cents per doz. SI.co per I0o.

Jersey Queen.(P) - It did finely with me the past season. Its uniformly large size, handsome appearance and fine quality, will always insure a ready sale at fancy prices, and I believe that with good culture few more profitable sorts can be grown. A neighboring fruit grower says it heads the list with him, among thirty varieties. 35 cents per dozen ; \$1.00 per 100.

Parry.-A seedling of the Jersey Queen, produced in ISSo by $\mathrm{Mr}$. Wm. Parry of New Jersey, fruited in ISSI, and awarded first premium at Moorestown Agricultural 


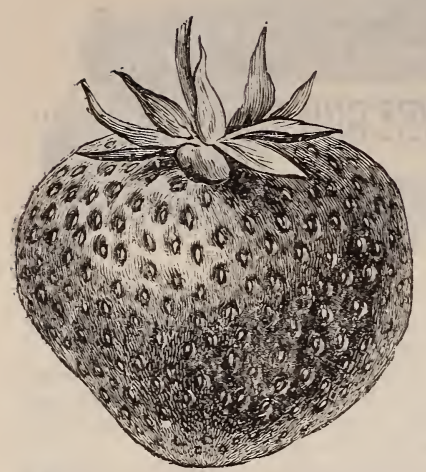

and Strawberry Fair. A severe drouth the latter part of the same seascn, destroyed almost every other variety in the same plot except the "Parry," from which the present stock was grown. It would seem from this trying ordeal that the "Parry," possesses great vitality, its hardiness and vigor enabling it to withs' and great heat and drouth. Plant productive, a strong, rotust grower, berries uniformly large in size, obtuse ccnic in shape, bright, glossy scarlet, firm, and of best quality, but little core, ripening all over at once, blosscms perfect, season medium. 50 cents per doz. \$2.00 per 100 .

Mrs. Garfield.-The plant is a good grower and bearer ; blossoms perfect ; season medium ; fruit medium to large ; of good form and color, and of excellent quality."

I was well pleased with this variety the past season, having fruited it for three seasons, I am inclined to think it valuable. 75 cents per dozen. $\$ 2.00$ per Ioo.

Connecticut Queen.-Excellent in quality, about the size of the Charles Downing. as productive as Crescent, and as firm as that variety ; perfect blossom very hardy, and a strong grower. 50 cents per dozen.

Prince of Berries.-A large, handsome berry, of the finest quality, in fact, I think the best in over two hundred varieties. A perfect flowering sort, and a reliable fertilizer for late pistilate varieties such as Jersey Queen, Manchester, \&:. 50 cents per dozen. \$1.50. per 100.

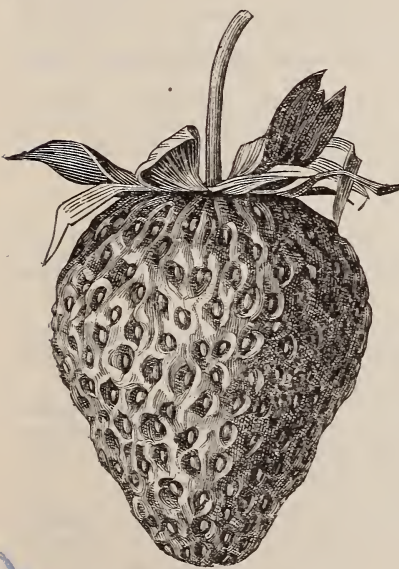

Atlantic.-This berry originated in the southern part of New Jersey, on a poor, sandy soil. It is a strong grower, resembling the Sharple's in this respect. Berries rather irregu. lar, conic sl, sometimes flattened, short necked, uniformly gcod size; color, bright crimson; flesh red and solid to center. A large bright green calyx adds materially to the appearance of the berry when picked. Season medium to late, ripening its main crop a week later than Wilson. Blossom perfect. Did very weil here the past season, bearing some very handsome berries of good quality, 50 cents per dozen; \$I.50 per Ioo.

Longfellow.-Does better than ever, and I have no doubt will continue to sustain everywhere the high reputation it has earned since ir was introduced. The plant is a strong grower, fruit very large, firm and of a habdsome, glossy, dark red color, exceedingly sweet, rich and high-flavored. With me under ordinary culture it is productive, and I think with a little extra care, would prove one of the most profitable sorts. 50 cents per dozen. $\$ 1.00$ per I0O.

James Vick.-This variety produced some fine berries early in the season, but did not seem able to keep up the size of the immense number that set la er in the season ; the berries however, were of good quality and fair size, and the plant is immensely productive. 50 cents per dozen. St.oo per Ioo. 
Warren.-I consider one of the best for home use, and valuable for market Season early. 50 cents per dozen; 75 cents per IOo.

Seneca Queen.-Being the first in the trade to diseminate this berry, and having grown it for several years myself, besides seeing it grown very largely for market in this and adjoining countie:, I have no hesitation in saying that it is unsurpassed by any of the older or newer sorts, as an early market variety, or for home use, and from

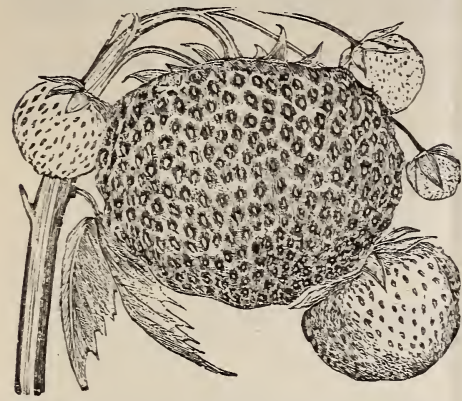
all parts of the country comes confirmation of this opinion. The plant is a remarkably strong, vigorous grower, and very productive; fruit of large size, and remaining so to the last picking; very uniform, of shape shown in engraving. color, dark red and of very fine quality. A litıle soft for shipment by rail, but firm enough for near by market, or transportation by boat. The above written in ISS1. After a thorough trial of it this year among oaler two hundred other varieties. I can only add that it has done better than ever, and that I consider it the very best early berry in general cultivation. They average almost as large the last picking as the first. 50 cents per doz. \$I.0O per 100.

Manchester, (P) - Although this berry came from a poor, sandy soll in New Jersey, it seems to succeed well on all soils, and in nearly all localities. Plant is rather inclined to burn in some places, but is a strong grower, fruit large, firm, uniform in shape and size, of a handsome scarlet color, very productive and of fair quality, season late. A valuable market variety. 50 cents per dozen; \$r.oo per Ioo.

Mt. Vernon or Kirkwood.-This berry did remarkably well with me the past season, both on sand and stiff clay. The berries are large, quite firm, of good quality, very smooth, and uniform in shape, and run large to the last picking. 50 cent; per dozen; \$1.0u per Ioo.

\section{STANDARD VARIETIES.}

Of most of the following varieties I have a large stock, and shall be pleased to quote special low rates by the 5,000 or 10,000 .

I have put all the following varieties at the uniform rate of $32 \mathrm{c}$. per dozen; 75c. per 100.

Capt. Jack.-With me, on strong, heavy, moist soil, this berry is immensely productive, even in matted rows, and if kept in narrow rows. and given good culture, it is a very valuable sort. Berry extremely firm and a splend d shipper; in shape resemble Wilson, but in se will average larger. Color, bright red; season medium to very late.

Charles Downing.-This is a very popular variety, and succeeds nearly everywhere and under all circumstances. Of large size, uniform, very procuctive, and of very good quality. Rather soft for long shipment. Season medium. \$4.0o per I,0oo.

Crescent Seedling (P).-For near by market is a profitable variety, it will endure neglect better than most sorts, and yet be enormously productive. \$2.50 per I,0s0: \$1 2.00 per 5,000.

Cumberland Triumph-A splendid early berry for home use or near by market. Berries of large size, very smooth and regular in shape, light red color. Its quality and firmness are very much improved when raised on light, dry soil. It has become a very popular variety for the amateur, as it ripens early and continues in bearing a long time.

Kentucky.-A valuable late variety, succeeding on all soils, and especially adapted for light sand. A vigorous grower, immensely productive, fruit large, firm, and of good quality. A recognized standard sort. \$4.00 per I,0ว0.

Miner's Prolific.-One of the best standard varieties. Berries very large, bright red, moderately firm, sweet, of very good quality. A vigorous grower and enormously productive. Season, medium. For near by market I believe it to be about the most profitable variety of the season that can be raised. $\$ 4.00$ per I, oco. 
Sharpless - Probably the largest berry in cultivation, specimens having meas ured twelve inches in circumference. Fruit rather irregular in shape; bright red color; moderately firm, very sweet and of good quality. Plant an enormous grower and productive. I picked many berries last season that were five and six inches in circumference, from beds set three years. \$4.00 per I,00J.

Wilson's Albany.-This old popular market variety is still unequalled by any of its season a; a shipper, but there are many far more profitable sorts for near market. $\$ 2.00$ per I,000; \$12.50 per 5,000.

In addition to the above, I have many varietie;, both new and cld, and can supply them in quantities desired.

Among the best early varieties I would name: Cumberland Triumph, Seneca Queen, Warren, and Old Irnn Clad.

Medium.-Sharples₹, Mrs. Garfield, Prince, and Daniel Boone.

Late.-CorNelia, Manchester, Jersey Queen, Longfellow and Mount Vernon.

\section{RESPPBERIES.}

Plant rows five feet apart, and three or four feet in the rows, on good soil and manure every year. Pinch back canes when three or four feet high, and cut back laterals the following year to within eighteen inches of the cane. Cut out all old wood each year, leaving three or four canes of the current season's growth, for fruit next year; treat all oiher suckers as weeds. Tender varieties should be grown longer so as to be laid down and covered with earth before winter.

If to go by mail, add 40 cents to the price per $5 \div$, and 75 cents to the price per 100 . Postpaid at dozen rates.

\section{VARIETIES.}

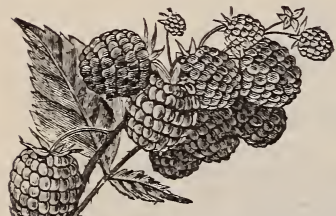

Marlboro.-This new VERY EARLY red raspberry is now offered for sale. It is the last of a long line of seedings; it has thus far proved PERFECTLY HARDY, and the strongest grower that I ever saw; immensely productive ; berries of the largest size, my plants produced many berries the past season, measuring $7 / 8$ inch cross diameter ; color, beautiful scarlet, and last but by no means least, the FIRMEST red raspberry that I ever

saw, making it pre-eminently "The MARKeT-BerRy." Up to last year it had never been fruited 'except in the Hudson-River region, but since then it has fruited in several localities in this state, New Jersey, Connecticut, \&c., and from every locality comes only the strongest commendations. The originator made his first picking of ripe berries last year on June 20 th, and made his first shipment on June $23 \mathrm{~d}$, " (this in the Hudson River region) being at least ten days earlier than the Cuthbert, which has been conceded by all to be the best berry that has been thoroughly tested.

I made first picking of ripe berries on June $30 t h$, and they continued in full bearing till July 30 th ; nearly as late as the Cuthbert, the berries averaging larger than the Cuthbert to the last picking.

[From Nathaniel Hallock, Esq.. the Introducer of the Antwerp Raspberry Business on the Hudson River, forty years ago.]

"On the failure of the Antwerp-which was once considered nearly perfect-I have thought that no variety would ever appear that would equal it; but having watched the New Marlboro closely, I am free to say that it has no qualities worse than the Antwerp, and niany superior. It is hardy, fruiting from the extremities when not protected : the most firm berry I have ever handled. It is of excellent flavor; keeps a greater length of time after being ripe aud it does not lose its brilliant crimson color. I know of none that will equal it in quality, size of fruit and growth of bush."

Plants grown from ROOT CUTTINGs and of superior quality, sent prepaid at the following rates. Io cents each; 75 cents per dozen; $\$ 3.00$ per 100. 


\section{THE NEW THURNLESS BLACK RASPBERRY.}

Springfield.-This new THORNLESS blackcap originated about ten years ago, at Springtield, Mass. The only party who has grown it in quantity for market, discarded all other varieties that he had, as unprofitable as compared with the " Springfield," as it is marketable before any other black-cap, ripening, as it does, before the last picking of the Sharpless Strawberry, it has been sold for 30 cents per quart box. It is a strong healthy grower, entirely free from rust and all other diseases, and immensely productive.

Its chief MERIT may be summed up as follows :

Season,--EARLIEST, ripens before any other black raspberry.

Size,-LARGE, similar to GREGG in size.

Gruwth,-VIGOROUs, even on poor soil, too rank on rich soil.

Constitution,-HEALTHY, has never shown any disease of leaf or cane. be put on."

Productiveness,-IMNENSE, visitors say, "don't see where any more berries cou'd

Quality,-EXCELLENT, better than many older varieties.

Hardiness, - PERFECTLY HARDY, never been known to winter-kill.

FREFDOM FROM THORNS, renders it easily gathered and cultivated.

It is MARKETABLF, on account of its extreme earliness before Southern blackberries; and at DOUBLE THE PRICE OF LATER VARIETIES.

Stock limited in quantity, but of fine quality. Order early ard test it.

SI.50 per dozen.

Beebe's Golden.-Originated abcut fire years ago in Chautauqua Co., N. I., the fruit is of bright cream or golden color, juice stainless ; very solid, three quarts canned said to be equal to four quarts of blackcaps, large, sweet, and of good flavor ; strong grower, perfectly hardy and very productive. 75 cents per dozen; $\$ 2$. co per Ioo. One year transplanted, $\$$ r.oo per dozen $; \$ 3.00$ per Ioo.

Rancocas.-Another new early red raspberry, offered for the first time, originating on the same farm as Hansell, a few days later than that variety, but said to be more productive ; and what is considered as a strong recommendation by some, is the fact that it ripens its whole crop in a few days. It has frui ed with me, and seems to be a fine, fruit and a good grower. 30 cents each; $\$ 3.00$ per dozen.

Nemaha.-A new Black Cép offered for first time this spring, as it bas not yet fruited with me I quote the following from Green's Fruit Grower :

"This variety originated with Hon. Robert Furnas, of Nebraska. Mr. Furnas says it has proved to be hardier than Gregg with him, and a meritorious var.ety. We have fruited it here two seasons. It has proved bardy, vigorous, of unsurpassed size and productive. Its season is even later than the Gregg. It is a firm berry, of good quality. Previous to the Nemaha we have hat no late variety that is haray. Early varieties ripen their wood and stop growing early, going into inter in good condition. But Gregg and Mammoth Cluster mature the fruit and hold their leaves very late, and winter finds them with soft and tender wood, and they often get injured by severe weather, especially is this the case on clayey, latish soil. On sandy soil they are more hardy. If Nemaha prove; to be more hardy, it will be a great gain, and IIr. Furnas is very positive that it is. Considering the large number of varieties of black caps, I should hesitate before introducing another without more thorough testing, but feel that Mr. Furnas's statements should have much weight. Visitors who have seen the Nemaha on our grounds, have said that it was the largest of all. Indeed I have picked larger specimens from it than from any other, yet I do not think the average size larger than Gregg. It is doubtful if we get a variety much larger. Perhaps we ought to be satisfied with such a giant." \$r.co per dozen.

$\checkmark$ Caroline.-This new variety is a yellow cap raised from seed of Brinckle's Orange, and it is suoposed to be a hybrid between that variety and the old Yellow-cap. In quality it is nearly equal to Brinckles' Orange, very productive and pe:fectly hardy. Too soft for shipment, but one of the best for home use. 50 cents per dozen ; \$2.co per Ioo.

Hillb rrn.-A new. Blackcap said to be of large size jet black color, excellent quality; only a few days later than Tyler; a strong grower, with few thorns, and very hardy. \$2.00 per dozen.

Hopkins.-An early Black Cap of good quality, resembles Mammoth Cluster, but a much better berry. Sr.oo per dozen. 
Shaffer's Colossal -A new variety claimed by the disseminator to be the "Largest raspberry in the world, as it averages picked from the field; also the most vigorous grower and exceedingly productive." It is a cap berry, propagating from tips. Berry quite firm, flesh sprightly, sub-acid, of a dark red color. It has been planted on a variety of soils from light sand to clay, and has proved equally vigorous on all. It appears to be an iron-clad in hardiness, (equaling the Turner in this respect) passing the most severe winters unprotected without injury. 50 cents per dozen; \$I.5O per roo; \$1 2.00 per I, 000.

Souhegan.-Has proved perfectly healthy and iron-clad. Originated in New Hampshire, but has been tested in many other States, and is highly praised by all who have grown it. Resembles the Tyler very much in appearance. 50 cents per dozen ; $\$ 1.50$ per I00; \$9.00 per I,000.

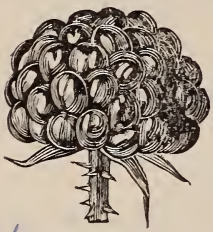

Tyler.-I have fruited the Tyler for three seasons past, and noted its ripening and productiveness in comparison with other varieties of black-caps, and have no hesitancy in saying that it combines more good qualities than any early blackcap before the public, for the same length of time. 50 cents per dozen; $\$$ r.50 per I00; \$9.00 per I,000.

Hansell.-Is believed to be as hardy as that iron-clad variety-the Turner ; is a good grower and productive; while the fruit is of the brightest crimson, of superior quality, and above all, very firm, having been shipped $40 \mathrm{~J}$ miles in good condition. 50 cents per dozen ; $\$ 3.00$ per I0ว.

Cuthbert, or Queen of the Market.-This splenilid berry still continues to grow in favor, and now stands at the head of the late red market varieties. Berries large in size, of a bright red, handsome color, very firm, can be shipped a long distance by rail, and always commands the highest price in market. Canes strong, vigorous, enormously productive, and perfectly healthy. Season medium to late. 50 cents per dozen; \$1.00 per 100; \$9.00 per I,000. Special rates on large quantities.

Herstine.-A large, bright red, handsome berry of the finest flavor. A strong, vigorous grower and very productive. Ripens very early, and is one of the finest for home use as well as for market. But half hardy and should have protection in winter. 50 cents per dozen ; $\$$ r.50 per Ioo; $\$$ ro.00 per I,000.

Turner.-A valuable market sort. Berries good size, sweet, rich and firm. A strong grower, very productive and extremely hardy, ripens early. 50 cents per doz.; $\$ 1.00$ fer $100 ; \$ 8.00$ per I,000.

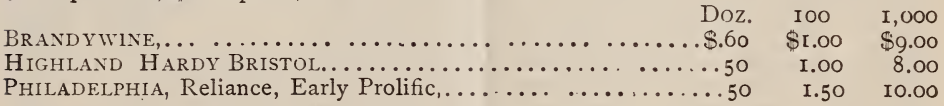

\section{LEADING CAP VARIETIES.}

Gregg.-A strong, vigorous grower, perfectly hardy, stands heat and drouth remarkably well, and produces enormous crops of jet-black berrie;, which, being free from bloom bring the highest price in market. It is very firm and can be shipped long distances without injury. Ripens about with the Mammoth Cluster. With Tyler for early and Gregg for late, no other black sorts are needed. 50 cents per dozen; $\$ 1.00$ per I00; $\$ 9.00$ per I.000.

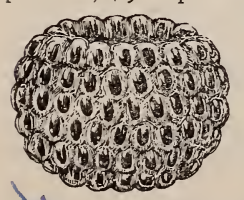

Ohio.-This variety has been grown quite extensively in Western New York for several years. It is very prolific, of good size, ripens about with Mammoth Cluster, and is a very profitable variety for drying purposes. 50 cents per dozen; \$I.00 per I00; \$8.00 per I,ogo.

Davison's Thornless/ Doolittle, Mammoth Cluster and Seneca.-Price 50 cents per dozen; $\$ 1.00$ per I00; $\$ 3.00$ per I,000. 


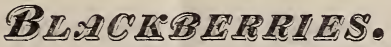

Give same cultivation as for raspberries. Partial shade is beneficial. Plant rows six to eight feet apart; and plants two or three feet apart in the rows.

If to go by mail, add 20 cents per dozen; 40 cents per 50: 75 cents fer Ioo to the price given.

Early Harvest. - Of fair size and excellent quality. 50 cents per doz; $\$ 2.00$. per Ioo.

Early Cluster.-A new berry, said to be hardy and productive, kerries medium to large size and of best quality. 20 cents each ; $\$ 1.50$ per dozen.

Wilson, Jr.-A new berry having a pedigree, grown from seed of Wilson's Early. - equaling its parent in every respect, but earlier and more productive, said to be the largest and best very early, Blackberry. \$1.50 per doz.

Wachusett Thornless.-This berry has done better each season for the last three years, and I think more of it every year. It is a strong healthy grower, hardy, and nearly free from thorns, making it extremely popular for home use ; on good ground and with good culture, it is immensely productive, berries of good size, very sweet, rich and of a fine flavor, $\$ 1.00$ per doz; $\$ 2.00$ per 100.

Stone's Hardy.-Mr. Stone describes it as follows : "An upright and vigorous grower, wood stocky, short jointed, ripens early, turns dark red and is very hardy. The berry is glossy black, has no hard core, and is delicious in flavor. It commences to ripen its fruit about five days later than the Snyder, and continues bearing ten days longer ; the fruit is well protected by the thick healthy foliage." $\$ .75$ per dozen $; \$ 3.00$ per Ioo.

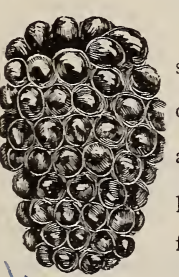

Snyder.-An exceedingly valuable sort. Berries remarkably sweet and fine flavored, free from core, and under good cultivation, of good size. So enormously productive it requires strong, rich soil and thorough culture to produce large berries. It has lost none of its popularity the past season, but still continues to give excellent satisfaction. 50 cents per dozen ; \$I.50 per Ioo.

Taylor's Prolific.-Taylor's Prol fic. like the Snyder, is fast growing in popularity. It has never been killed here, even during the most severe winter, and besides possesses the great merit of being enormously productive, of large sized, sweet and fine flavored berries, which are ripe when black. Price 50 cents per dozen; $\$ 2.00$ per 100 .

Zittatinny.-An old and popular variety. Large, fine flavored, vigorous and. productive. Half hardy. 50 cents per dozen ; \$1.50 per $100 ; \$ 9$. per I,000.

$\checkmark$ Wilson's Early.-Very early, of large size and handsome appearance; rather tender, but a very profitable sort. 50 cents per dozen ; \$1.50 per I00 ; \$9. per I,000.

Lawton or New Rochelle-A well known reliable variety. An enormous. bearer. Half hardy. 50 cents per dozen ; $\$ 1.50$ per Ioo.

Lucretia and Mammoth Dewberry. -30 cents each ; $\$ 3.00$ per dozen.

Erie.-A new berry said to combine all the qualities that fruit growers have been looking for. An iron-clad from northern Ohio. Not yet offered to the public.

Minnewaski.-Another new berry from the Hudson River will be offered next fall, well spoken of by all who have seen it.

\section{CUU゚RRANTS}

Set in rows six feet apart, and three feet in the rows for field culture, can be planted much closer for garden culture. Thorough cultivation, enriching and pruning will pay in growing currants. Coal ashes around the roots will keep out the borer, and hellebore will kill the currant worm. Dust on the hellebore early in the season, and repeat s 0 ? ten as the worm is seen. A mulch in summer is very beneficial. If to go by mail ad 120 cents per dozen; None but one year plants sent by mail. 
Fay's Prolific.-" A seedling of the Cherry and Victoria currants. Color, rich red. As compared with the Cherry currant, Fay's Prolific is equal in size, better in flavor, with much less acid and five times more prolific; also from its peculiar stem, less expensive too pick." Strong one year plants, to cents each ; $\$ 4.00$ per dozen ; two years plants 70 cents each ; $\$ 7.00$ per dozen.

Cherry.-Bunch large, berries of the largest size, of handsome color and good quality. One year 60 cents per dozen ; $\$ 3.50$ per roo. Two years, 75 cents per dozen ; $\$ 4.00$ per I0o.

Versailles.-Very similar to above. Price same as Cherry.

White Grape.-A very fine variety, especially for table use. Price same as Cherry.

Victoria.-An exceedingly valuable very late sort; berries large, handsome and fine flavored. A strong, vigorous grower and immensely productive. Its extreme lateness makes it the most profitable sort for market. Price same as Cherry.

Lee's Prolific.--Black, berries very large, best quality; a vigorous grower and immensely productive. Price same as Cherry.

(

Black Naples two years ....

Red Dutch, Nvite Gondois, White Dutch, one year

" " " " " two years
Doz.

$\$ 50$

50

75
Ioo

$\$ 200$

3 oo

400
IOOO.

SI5 00

3000

3500

\section{COOOSEBERTES.}

The same remarks apply to Gooseberries as to Currants. Pos age same as for Currants.

$\checkmark$ Downing.-The best variety, all things considered, for home use or market; vigorous and productive, and less apt to mildew than most sorts. Si.50 per doz. Ioo.

Houghton. - An old and reliable sort. One year, 50 cents per dozen; $\$ 3.00$ per

Smith's Improved.-Large, handsome yellow color, and fine flavored. \$1.00 per doz.

Industry.-Very large, red ; of fine quality and excellent flavor, a NEW English variety, promises to succeed here. 35 cents each ; $\$ 4.00$ per doz. page of cover.

Auburn and Hudson, 50 cents each.

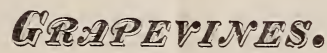

Choice kinds require choice culture, and I do not recommend all varieties for every locality. The Concord and Rogers' Hybrids are perhaps more universally successful than any others, yet they do not succeed everywhere. Manuals on the cultivation of the grape are so abundant, and the systematic training of the vine requires so much space of detail, that I shall not attempt to do it here. A well drained, deep, shady soil gives the best results. Whatever system is pursued, remember to give free growing varieties plenty of room, and that the best of fruit grows on shoots from the wood of the previous year. The following list comprises what are considered the "cream" of the old, as well as the best of the newer sorts. Postage on one year vines, 20 cents per dozen, 2 years 30 cents per doz. Single vines post paid. No vines mailed at 100 rates.

\section{NEW VARIETIES.}

Cayuga.-A new very early black grape, originated in Jefferson Co., N. Y.., perfectly hardy, as early as Champion, as large as Isabella, which it resembles in flavor, a strong, healthy grower and very productive. I year, \$I.5O each; 2 years, \$2.co each. 
Empire State.-“A purely native variety, a remarkably strong grower; extremely hardy ; very productive ; very early ; best quality, being free from foxiness : hangs firmly to the stem ; continues a long time in season on the vine, and is a remarkably good keeper." One year, \$1.50 each ; two years, \$2.00 each.

Woodruff Red.-A new seedling of the Concord originated at Ann Arbor. Mich., a very handsome grape, bunch large, shouldered, berry very large and does not drop from stem. It is an excellent keeper, having been kept on a shelf in cellar till the last week in December and eaten from the stems. One year \$I each ; \$10.00 per dozen. Two years $\$ 1.50$ each ; $\$ 15.00$ per dozen.

Ulster Prolific - "A cross of the Catawba (which it resembles in size and color of berry and shape of cluster,) and a wild grape of the forest. It forms its berries so early that rose bugs never attack its foliage. It ripens here from the first to the middle of September, and is as hardy, as the wildest vine of the woods." I year, SI.00 each ; 2 years $\$ 1.50$.

Poughkeepsie Red.- "A Cross of Delaware and Iona, vine resembling Delaware in wood and foliage, but a much better grower, will succeed where the Delaware will not. Clusters average from size of Delaware to twice as large; and in excellence of fruit is the first one ever introduced in America that can be called perfect. By perfect, we mean nothing objectionable in it to eat, in skin or flesh, much better in quali. ty than Delaware." One year. \$1 each; 2 years, $\$ 1.50$.

Niagara.-A purely native white grape, hardy, early, good quality, and productive; colored plate mailed for 3 cent stamp. For further particulars send for special circular. Strong two years with stal, \$2.00;\$17.00 per 1o; \$150 per Ioo.

Jessica.-A Canadian seedling white grape. VERY EARLY, being in eating condition before Champion in same vineyard. Berries larger than Delaware, very sweet, rich, and of a most delightful flavor. Color, greenish yellow, turning to a light amber when fully ripe; hardy as Concord, very productive.

Fruit I had of it was very fine, and I think no one will be disappointed in trying this grape. I year vines, 50 cents each ; 2 years $\$ 1$.00 each.

Vergennes.-A new and promising variety. Clusters large, berries Iarge, light amber; flavor rich and delicious, eariy, ripens early and is a good keeper. Very hardy and productive. One year 35 cents each $; \$ 3.50$ per doz. 2 years 50 cents each ; $\$ 5.00$ per coz.

Early Victor.-A new extra early black grape of great promise, originated in Kansas. One year vines, 35 cents each, $\$ 3.50$ per dozen; 2 years 50 cents each, $\$ 5.00$ per doz

Duchess.-Bunch medium to large, berry medium, round, of greenish white color. changing to a beautiful amber when fully ripe, flesh tender, without pulp, and in flavor will rank as best. One year, 35 cents each $; \$ 3.50$ per doz. Two years 50 cents each ; $\$ 5.00$ per doz.

Centennial.- " Bunch medium to large, compact, sometimes shouldered, berries medium, round, skin thick, tough, tenacious; pulp sweet, tender, juicy, rich; vinous, sugary, sprightly, refeshing, abundant ; berry light red, transparent, no harshness or acidity, aromatic, quality for table or wine, best; thin white bloom, must scale not tested." One year, 50 cents each ; two years 75 cents each.

$\checkmark$ Lady Washington.-Deep yellow, sometimes tinged with pink; flesh soft, tender, sweet and juicy; vine hardy and healthy; very handsome and showy. One year, 30 cents each ; $\$ 3.50$ per doz. Two years 50 cents each, $\$ 5.00$ per doz.

Jefferson.- - Very hardy, a strong grower and productive. Bunch large, shouldered, berry large, light red ; flesh meaty, tender, juicy and sweet, of the best quality. A very valuable and promising variety. One year vines 40 cents each; $\$ 4.00$ per doz; 2 years, 60 cents each ; $\$ 6.00$ per doz.

Pocklington.-A seedling of Concord ; strong grower, healthy, and hardy, never having been known to mildew or winter kill. Very large, light yellow, covered with a fine bloom, of as good or better quality than Concord and ripens about the same time. One year vines 25 cents each, $\$ 2.50$ per doz. 2 years 35 cents $\epsilon$ ach, $\$ 3.50$ per doz.

Prentiss.-Yellowish green; skin thin but firm; flesh tender, sweet, melting and juicy. Ripens with Concord. One year 25 cents each; $\$ 2.50$ per doz. Two years, 40 cents each ; $\$ 4.00$ per doz.

楁 SPECIAL OFFER.-I will send one good, strong one year vine of each of the above named sorts, fifteen vines in all, for $\$ 8.00$, or one two year vine of each for \$I I.co by mail postpaid. 


\section{STANDARD VARIE'IIES.}

Brighton.-A popular sort. Berry medium to large, deep red, very sweet, rich and h.gh flavored, hardy and productive. One year, 25 cents each; \$2.50 per doz. Two years 35 cents each ; $\$ 3.50$ per doz.

Lady.-A valuable early white grape. Berry large with thin skin and of good quality, healthy and hardy. One year 20 cents each; 2.00 per doz. Two years, strong, 30 cents each; $\$ 3.00$ per doz.

Moore's Early.-Very early, ripening two weeks before the Concord. Bunch large. Berry large, round, black, with a heavy blue bloom; hardy and productive. One year, 30 cents each ; $\$ 300$ per doz. Two years, 50 cents each, $\$ 5,00$ per doz.

Worden.-A seedling of and similar to the Concord in appearance, but the berries are much larger, of better flavor, and ripen earlier. Strong one year 20 cen's each; $\$ 2.00$ per doz. 'Two year:, 30 cents each, $\$ 3.00$ per doz.

Each. Doz. 100

Agaway, Lindidey, Salem (Rogers, I 5, 9, 53,) Red. I year.... I5 \$2 oo \$1o oo

" " . ". "." 2 year....25 $250 \quad 1500$

Catawba, Red I year............................. I5 I $50 \quad 6$ oо

" 2 year...............................

Champiox or TALMAN, Black, I year.................... 2 15 $200 \quad 900$

COXCORD BLACK, I year.....................................

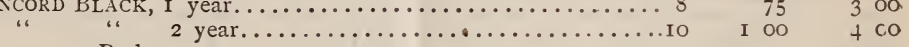

DELAWARE Red, I year.................................. 20 I

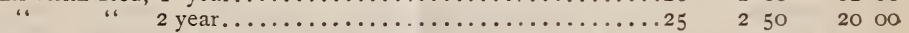

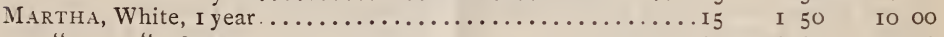

“

Wilder, (Rogers' 4) MERRIMACK (Rogers' I9) Black, I year...15 2 oo 10 10 00

2 year...25 $250 \quad 1500$ above named, "Standard Varieties" thirteen vines, in all for year vine of each of the vine of each for $\$ 3.00$ by mallpost paid.

\section{FRUTT TREES.}

N. B. I have an especially fine and well-grown stock of fruit trees of all kinds, and to those about to plant large quantities I am prepared to offer special inducements. I wish to call particular attention to a very large and fine stock of $I$ and 2 year old trees of a light grade, especially adapted for long distance shipment, as they can be transported for less than half the cost of larger trees and are far more certain to live and growe well.

\section{APPLES.}

The best known, the most extensively grown, and the most consumed of all fruits, need no words of commendation and I have only to advise the planter to make a careful selection of varieties suited to his locality'; few in number, if for orchard planting; a good var.ety of summer, fall and winter sorts, if for family use.

Each. Doz. 100. STANDARD, leading varieties, 5 to 6 feet............. $\$ 25$ \$2 50 \$20 oo

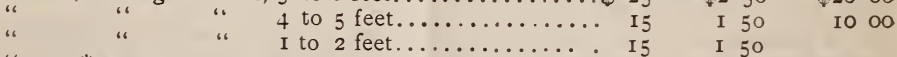

" *newer " t to 5 feet................. 30.350

* Neiver and Extra-Priced Sorts.-Haas, Lady App!e, II Intosh Red, Rubicon, Walbridge, Wealthy, Stump.

Alexander (Emperor).-Very hardy, fruit large, red, crisp, tender and juicy. October to December. 40 cents each.

Mann.- Very hardy and productive; fruit very fair, handsome, and placed next to the Baldwin in va'ue as a market apple. A wonderful keeper, January to July. 40
cents each. 


\section{CRAB APPLES.}

Selected trees, 5 to 6 feet, 25 cents each : $\varsigma_{3.00}$ per dozen.

Leading VARIETIEs.-Hyslop, Red and Yellow Siberian, Transcendent.

Gen. Grant.-Large, white flesh, moderately fine grained; 30 cents each.

\section{PEARS.}

The higher flavor, juciness and aroma of the pear, rank it above the apple and increase its value, and its production demands the best soil and the highest culture. A strong clay loam, surface cultured and manured, suits it best.

The following list of varieties includes only those of tried merit as to growth, froductiveness and quality; those which are most in general demand and of which my stock generally consists.
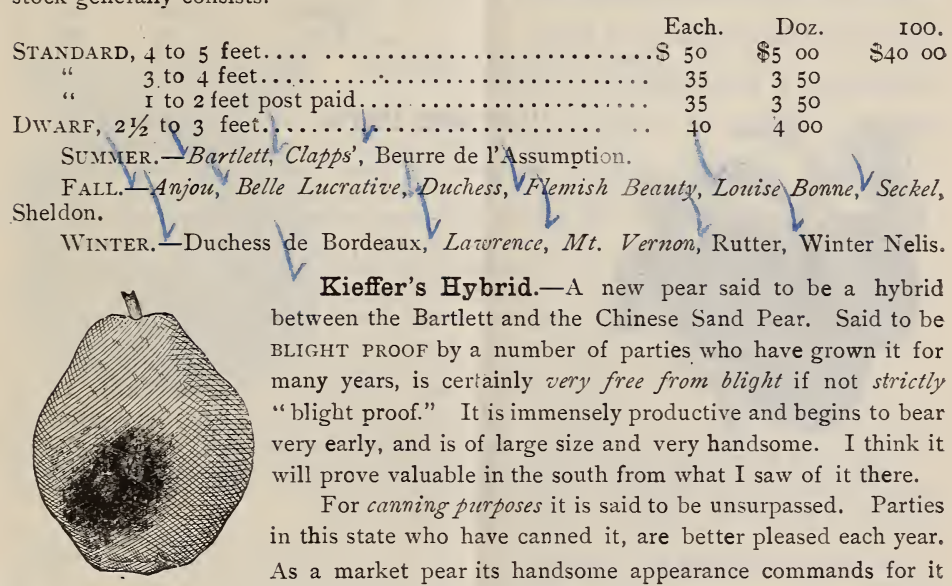

Kieffer's Hybrid.-A new pear said to be a hybrid between the Bartlett and the Chinese Sand Pear. Said to be BLIGHT PROOF by a number of parties who have grown it for many years, is certainly very free from blight if not strictly "blight proof." It is immensely productive and begins to bear very early, and is of large size and very handsome. I think it will prove valuable in the south from what I saw of it there.

For canning purposes it is said to be unsurpassed. Parties in this state who have canned it, are better pleased each year. As a market pear its handsome appearance commands for it the highest prices.

Standard, I year, 40 cents each, $\$+$ per dozen; 2 years, 60 cents each, $\$ 6.00$ per doz. I yea:, I to 2 feet, 50 cents each, by mail, post paid.

Souvenir $\mathrm{Du}$ Congress.-A very large, handsome summer pear, resembling the Bartlett, but larger. 60 cents each ; $\$ 6.00$ per dozen.

$\checkmark$ President Drouard.-Recently introduced from France. Tree a strong grower ; fruit large, melting and juicy. Ripens from March to May. $60 \mathrm{cts}$. each; $\$ 6.00$ per doz.

\section{CHERRIES.}

The cherry requires a dry soil, not too rich. The sweet sorts are rapid growers with soft, drooping foliage. The sour sorts are more slender and spreading in growth and can be planted much closer together without detriment.

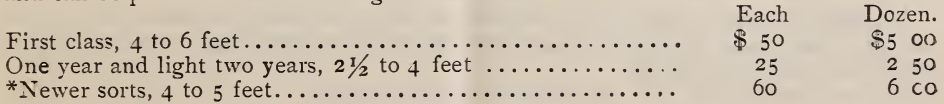

\section{LEADING VARIETIES.}

Souk.-English Moreklo, Early Richmonl, May Duke, Reine Hortense.

SweetY-Black Eagle, Black Tartarian, Gov. Wood, Yellow Spanish. 


\section{*NEWER SORTS.}

Olivet.-A new variety from France. Large red, sour. Ripens middle of June. Montmorency (Ordinaire.)-New, larger than Early Richmond (which it resembles) and ten days later. Very hardy and prolific.

Empress Eugenie.-Large, rich dark red. Middle of June.

Luelling.-Black, flesh solid, sweet, and of the finest quality.

\section{PLUIMS.}

A rich, strong soil best suits the plum. Good cultivation and regular fertilizing are required. If " black knot" should appear cut out at once and burn. The curculio must be closely watched during the formation of the fruit. Every morning jar down on sheets both insects and stung fruit.

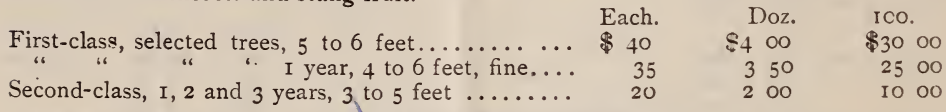

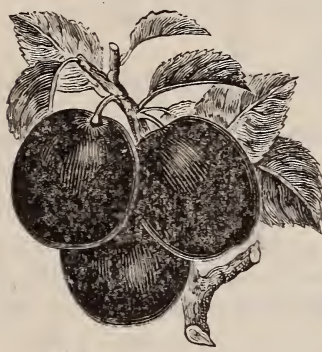

SHIPPERS PRIDE.-(See cut reduced first page of cover.) This plum originated in western New Iork, near the shores ci Lake Ontario, and hasn ever been known to freeze back in the severest winters. Fruit of large size ; color, dark purple; flesh firm, of good quality and very productive ; season Ist to $\mathrm{I} 5^{\text {, }} \mathrm{h}$ of September.

N. B. Having purchased the stock of this Plum FORMERLY OWNED by H. S. WILEY, being the undivided half owned by Wiley \& Mersereau (the "original iutroducers ") I have by" far the LARGEST and ONLY STOCK of 2 YEAR TREES (except what were bought of Mr Mersereau and myself last fall) of SHIPPERS PRIDE PLUM. We have also the LARGEST STOCK and finest grown I YEAR, some of them measuring EIGHT FEET in height.

Send for special circular giving testimonials and much valuable information in regard to this Plum. Beautiful COLORED PLATE free to every purchaser of this variety, or mailed for 5 cents.

Each. Doz.

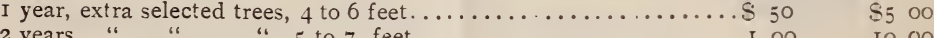
2 years, " " 5 to 7 feet..................

\section{PEACHES.}

A warm, sandy soil is best, hut stronger soils, dry and thoroughly worked, will grow them. Ashes thrown about the collar of the tree is a useful protection against the borer.

Each. Doz. Ioo. 1000.

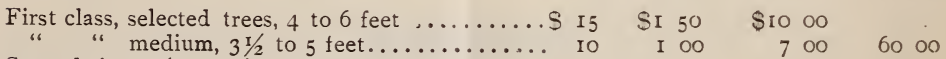
Second size $2 \frac{1}{2}$ to $3 \frac{1}{2}$ feet, good size for orchards $\quad$ IO $\quad$ I $00 \quad 500 \quad 4500$ Small trees and trees in bud, by mail postpaid.... Io I 00

Globe.-A new variety from $\mathrm{Pa}$. Yellow, freestone, hardy, large size, fine quality, productive. 50 cents to $\$ 1.00$ each; $\$ 4.50$ to 9.00 per doz.

$\checkmark$ Pratt Peach.-Season Ist of September, large size, small pit, flesh yellow, tender and juicy; said to reproduce itself true, from the pit every time, very hardy, and a regular and abundant bearer.

I year seedlings 50 cents each; budded trees 25 each.

Brigdon or Garfield - This new peach originated within ten miles of me in the town of Fleming, the fruit is of large size, good quality and handsome appearance. Resembles the Early Crawford; season middle of September. 20 cents each; $\$ 2.00$ per dozen.

Wager.-Large, yellow, red in the sun; juicy and of fine flavor. An annual and abundant bearer. Kipens last of August, 20 cents each; $\$ 2.25$ per dozen. 
Wheatland.-"Ripening between the early and late Crawfords ; fu'ly equal in size, better in quality, and more desirable for the table than either of these two well known varieties." 20 cents each; $\$ 2.00$ per dozen; \$Io per Ioo. Second size Io cents each.

\section{APRICOTS.}

Early Golden, (middle of July); Moorpark, (middle of August); Peach, (August). first class, 25 cents eaca : $\$ 2.50$ per dozen.

Russian Apricot. - I year, 50 cents each ; \$5.00 per dozen.

\section{QUINCES.}

A rich, mellow soil, good culiure and annual manuring are requisite to success. Plant twelve feet apart. Keep branches and fruit thinned.

Champion Quince.-The largest yet produced; fruit fair, smooth, and of the finest quality. Two weeks later than the Orange and a much bitter keeper, bearing at two to four years of age. One year $21 / 2$ to 4 feet, 35 cents each; $\$ 3.50$ per dozen. One year I to 2 feet, 25 cents each.

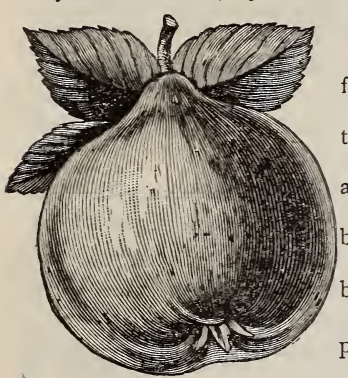

Meech's Prolific.--This new Quince is now offered for sale, and the disseminators claim among other things, that the tree is a very strong grower, an early and abundant bearer, the fruit is of very large size, beautiful appearance, and delicious flavor, and last but by no means least that it's cooking qualities are unsurpassed. I year trees, SI.50 each.

Orange or Apple.-The standard variety. October, I to 2 feet, $I_{5}$ cents each, $\$ 1.50$ perdozen; \$IO.00 per IOO. 2 to 3 feet, 25 cents; $\$ 2.50$ per dozen; \$2O per 100 .

Rea's Mammoth. $-2 \frac{1}{2}$ to 4 feet, 50 cents each ; $\$ 5$ per dozen.

\section{MULBERRIES.}

Downing's Everbearing.-Very large, sweet, rich and desirable. Color, black ; 3 to + feet trees, 50 cents each; $\$ 5.00$ per dozen.

White.-Cultivated largely for food for silk worms. 25 cents each, \$2.0o per dozen.

Russian.-Said to be a very early and abundant bearer ; fruit very large, black. A very rapid grower; I to $I \frac{1}{2}$ feet by mail, postpaid, 20 cents each. I $1 / 2$ to 2 feet, 20 cents each: \$2.00 per dozen. 3 to 4 feet, 30 cents each; $\$ 3.00$ per doz.

Asparagus, Conover's Colossal.-Very large, a strong, rapid grower. The most reliable sort. Year roots, $\$ 1.00$ per $100 ; \$ 4.00$ per 1,$000 ;$ two years, $\$ 1.00$ per Ioo; $\$ 0.00$ per $\mathbf{r}, 000$. Special rates on larger quantities. Postage 30 cents per Ioo for one year roots. No two year roots mailed.

\section{ROSES.} doz.

Mailed postpaid at single rates when desired. Small plants by mail at \$I.oolper

Of these I have an unusually fine and well-grown stock, just received from France, from which I offer the following choice assortment. Parties desiring a large assortment are referred to catalogue No. 3 of Roses, giving a list of over 200 varieties, with directions for their culture, treatment of insect enemies, etc. Mailed free on application. noted.

Ever Blooming.-Price 25 cents each ; \$2.50 per doz., except where otherwise

VArieties.-Aggripina, Bon Silene, Cornelia Cook, Duchess de Brabant, Hermosa, Isabella Sprunt, Marshal Niel, Saffrano, WThite Tea.

Newer Sorts.-Duchess of Edinburgh, Climbing Hermosa, Pearl de Lyon. 50 cents each: $\$ 5.00$ per doz. 
Hybrid Perpetual. - Price 30 cents each ; $\$ 3.00$ per doz; $\$ 20.00$ per roo.

VARIETIEs.-Baron Prevost, Belle de Normandy, Gen. Washington, Giant of Battles, Gen. Tacqueminot, John Hopper, La Reine, Mad. Plantier, Pæonia, Pius IX, Prince Camille de Rohan, Triomphe de l'Exposition.

$\checkmark$ Climbing.-Price 25 cents each; $\$ 2.50$ per doz.

VARIETIES.-Baltimore Belle, Gem of Prairie, Pride of Washington, Queen of Prairie.

Moss.-Price 50 cents each; $\$ 5.00$ per doz.

Varieties.-Glory of Mosses, Red, White, Henry Martin, Wm. Lobb.

\section{CLEMATIS (VIRGIN'S BOWER.)}

The Clematis is the most popular climbing and flowering plant of the day, as they are entirely hardy, and bloom during the entire season, in color embracing the most beautiful shades of blue, purple, lavender, scarlet, white, etc., double and single, some of them 6 inches in diameter; and by careful training attain a height of from 5 to $\mathrm{I}+$ feet in a season.

The following list embraces a fine assortment, and they can be sent with perfect safety by mail postpaid, at any time durng the year. The second size are good plants.

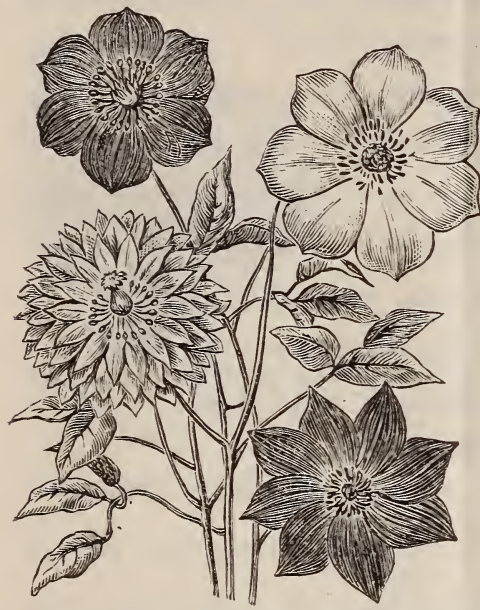

Dichess of Edinburgh.- - Very fine double white.

FaIR Rosamond.-Blush white, wine colored bars.

JACKMANni.-Dark rich purple; a perfect mass of flowers when in full bloom. Ist size, 75 cents, $2 \mathrm{~d}$ size 50 cents.

Languinosa Candiga,-White, tinted lilac.

Lawsoniana - Rosy purple, with dark veins.

RUbelt.A.-Velvet claret purple; distinct and free.

The QueEx.-Delicate lavender, flowers 6 inches in diameter.

SeNSATION.-Rich, satiny, maure, flowers large and showy.

Prices of above, except where noted, first size, 75 cents ; $2 \mathrm{~d}$ size, 50 cents each.

\section{THE NEW SCARLET CLEMATIS COCCINEA.}

(See cut.)

This remarkably handsome climbing plant, after several years trial, has proved to be one of the most desirable for any purpose where climbing plants are required. The plant is an herbacenus perennial, the stem dying to the surface each winter, (this is an advantage where an unobstructed view is required in winter); the vines attain the height of from 8 to Io or 12 feet, bezinning to flower in June and continuing until frost ; single vines have from 20 to 30 flowers on each, and frequently as many as ten vines will start from one crown each season.

As will be seen by the cut, the flowers are bell-shaped ; in color a rich deep coralscarlet, shining as if polished and lasting a long time when cut. Indeed one of the most beautiful plants for festooning, is to be found in CLEMATIS CocCINEA, with its peculiarly shaded green and elegantly cut and varied foliage-if it never flowered it would be a handsome climbing vine.

The plant during our observation, has no insect pest or enemies; it grows freely in any soil, requiring only one or two hours sunshine to strengthen the vine sufficiently to make a successful flowering season, and above all is perfec ly hardy, standing exposure in our severest winters without harm. 25 cents each, $\$ 2.50$ per doz. Colored plate mailed for 5 cents. 


\section{THE NEW BLUE CLEMATIS CRISPA.}

This is a lovely companion to the Clematis Coccinea; it has splendid bell-shaped Howers, of a delicate violet blue, and of Most delicious fragrance. 30 cents each.

Everybody should have these two Clematis. I will mail them both for $+5 \mathrm{cts}$.

Set of Io first size, $\$ 6.00$; set of ten second size, $\$+.50$

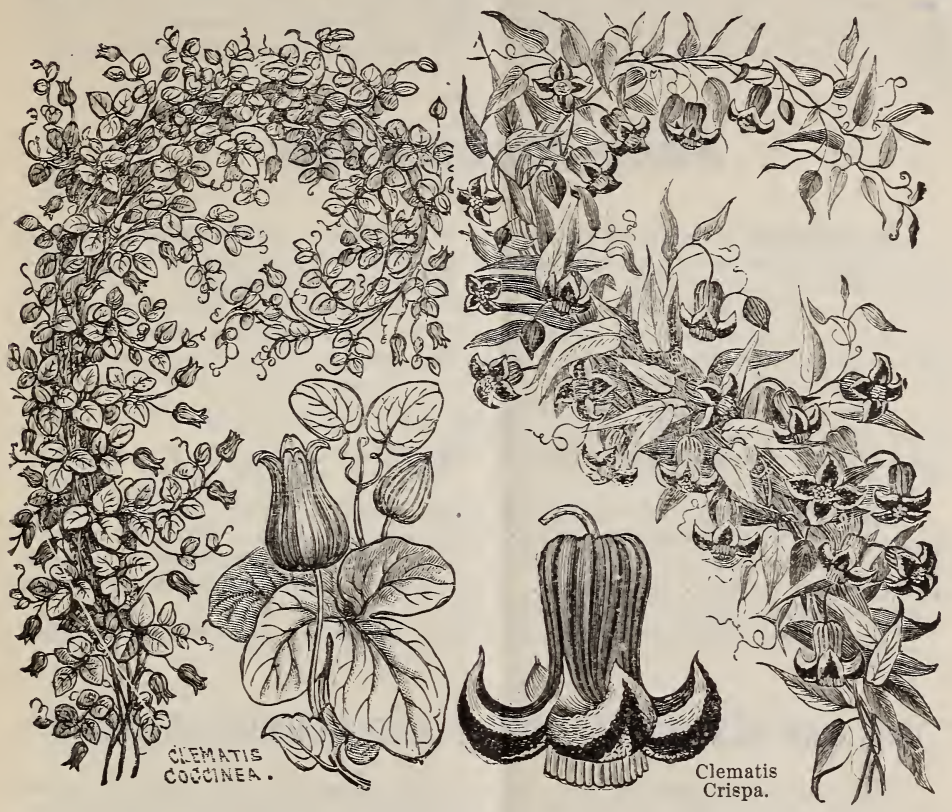

PRUNUS PISCARDII.

This sp'endid novelty was imported from Persia : it is a flowerins plum, but is particularly attractive on account of its beautiful foliage, which is of a blood red color, which it retains a greater length of time than the Purple Beech or any other purple leared tree or shrub with which I am acquainted, it is hardy and a fine grower.

I year trees, I to 2 feet, 25 cents each. I year trees, 2 to 3 feet, 50 cents each ; 3 to 4 feet 75 cents each; smaller plants, postpaid by mail at same price.

Ampelopsis Veitcheii. (Japanese Ivy) - This beautiful climber is fast becoming a general favorite ; as a wall plant it has no superior, as it will cling to the smoothest surface. In the autumn the beauty of its foliage is very striking. 20 cents each.

American Ivy, Virginia Creeper, Woodbine, as it is variously called, is a more rapid grower than the preceding one, is a native of this country, and has the same beautiful change of color in its foliage in autumn. I5 cents each.

Hydrangea, Paniculata Grandiflora, a hardy shrub of great beauty when in bloom, the flowers, $u$ hite in color, sometimes being nearly a foot each way. 25 cents and 50 cents according to size.

Pansies.-Fine selected plants, 50 cents per doz. postpaid.

\section{VALUABD E COUNTRY RESIDERCE FOR SALE TH, VULUBLE COUNT R RESOEICEFOR SALE. residence of the late Dr. H. H. Farley, containing about 35 . ACR Es, half in bearing Vineyard, Pear Orchard, account of death of former owner. For particulars, address. A rovely place for a Country Hame. Sold only on




\section{POTETTESS}

Dakota Red.-New: Tubers very large; not red, but darker than the Early Rose ; eyes quite deeply set ; skin rough and netted ; growth of top exceptionally strong, and so far as we know has never shown a sign of blight. As a variety to grow for heavy yield it is one of the best, and we think it will give good satisfaction for table use, as it cooks well and is of excellent quality, either baked or boiled; lb., 60 cts. post paid; peck, 50 cents ; bushel, \$1.00. Price for larger quantities given on application.

\section{SEED ETELD CORN.}

Waushakum. -Described by originator as follows : "The Waushakum Corn is an eight rowed yellow corn of the Canadian type ; the ear cylindrical, about 9 inches long ; the kernel long and deep, the color rich and glossy. The weight of the seed corn is fully 60 pounds, and in samples $6+$ pounds to the struck bushel. This corn was bred ivy a process of selection. We passed through the field before the period of bloom and cut away the barren and imperfect stalks, thus securing a fecund male parentage." It is probably the highest bred type of the Flint sorts and worthy of a trial by any one who wishes to grow a flint variety. Price per ear, 20 cents ; peck, 75 cents ; bushel, $\$ 2.00$ which includes new grain bag for shipping.

"The Waushakum is a splendid corn with me."-John Brows, Waushara Co., Wis. Latitude 450 .

King Philip.-One of the oldest and best known of the flint varieties. I recommend it to its old friends who will probably be glad to have it again, for its early maturity, (said to ripen in three months.) I have thoroughbred grown seed of this kind, large sized and handsome selected ears. Pkt., Io cents; pint, post paid, 25 cents; ear 20 cents; 100 ears, $\$ 2.00$; bushel, shelled, $\$ 2.00$.

I have grown both of above varieties the past season and find them very satisfactory sorts.

\section{"THE GARDENERS' MONTHLY AND HORTICULTURIST,"}

Edited by Thomas Meehan, and published at $\$ 2.00$ per year, gives full instructions in the science and practice of every branch of gardening. It will pay any one to subscribe for it.

Our friends and customers may send their subscriptions through us, if they prefer, and we will forward them to the publisher. Address

H. S. ANDERSON.

Union Springs, N. Y.

YOTICE - I take pleasure in calling the attention of my customers to the following 1U11. Advertisements. I have admitted none but what I believe to be reliable, and the advertisers responsible and willing to fullfill their engagements.

H. S. ANDERSON.

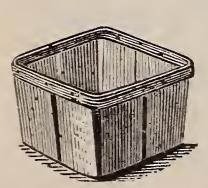

BERRY CRATES,

BERRY BASKETS, SHIPPING:BASKETS.

Our Crates and Easkets are not excelled by any others. Recommended and used by all the largest growers of small fruits. Once tried always satisfied. The best goods and the lowest prices, give us a trial order. ia Price list Free.

F. D. BANCROFT \& CO., West Webster,:N. Y. 


\section{That Grand FRUIT BOOK, THOMAS' AMERICAN FRUIT CULTURIST. Froe to Fvorybody.}

One of the very best books ever written on Fruit Culture in all jts branches. By John J. Thomas, editor of the Country Gentleman. Latest revised edition; re-written and brought down to date; fully illustraterl; containing 593 pages and bound in cloth. This is no cheap book in paper covers; but a finely printed ard well bound book.

It is given to every subscriber to THE AMERICAN GARDEN who sends $\$ 200$ for a year's subscription to the publisher, and adds 15 cts. for posiage on the book.

THE AMERICAN GARDEx is an illustrated, handsomely printed monthly rnagazine of 32 pages; owned, written, and edited by practical men for practical people. Subscription price $\$ 2.00$ a year. Single number 20 cts.

E. H. LibBr, publisher, 47 Dey St., New York. and Greentield, Mass.

\section{JW IMARERTLOUS RRICES. B BOOKS FOR THE MILLION}

Complete Novels and Other Works, by Famous Authors, Almost Given Away!

The following hooks arc published in neat pamphlet form, many of them handsom cly illustrated, and all are printci? from good ty pe upon good paper. They treat of a great variety of subjccts, and we thiuk uo one can ex:uninc the
list whthout fiudiug theren many that he or she would like to possess. In cloth-bound form these books would cost $\$ 1.00$ list without fiudiug theren many that
each. Each book is complete in itself.

1. The Widow Bedott Papers. This is the book over which your graudmothers laughed till they cricd, and it is just as funuy to-day as it erer was.

2. Faney Work for Home Adornment, an en. tirely uew work upon this subject, containing easy aud practical instructions for making fancy baskets, wal pockets, brackets, needle work,
fusely and elegantly illustrated.

3. Grimm's Fuiry Storles for the Young. The 3. Grimm's Fuiry Storles for the Young. The
finest collection of fairy stories ever published. The chilifinest collection of fairy stories ever
ren will be delighted with them.

4. The Lady of the Lake. By Sir Walter Scott. "The Lady of the Lake" is a romance in verse, and of all

5. Manual of Etiquetle for Ladies and Gentlemen, a guide to politeness and good breeding, giring the rules of codern etiquette for all occasions.

6. The Standard Letter Writer for Ladies and Gentlemen a coniplete guide to correspondence, giviug glain directions for the composition of letters of giviug kind, with innumerable forms and examples.

7. Winter Evening Reereatious, a large collection of Acting Charades, Tibleaux, Gaues, Puzzles, etc. for social gatherings, private theatricals, and eveuings a bome; illustrated.

8. Dialogues, Recitations and Readings, a largc and choice collection for school exhibitions and public and private entertainments.

9. Parlor Magic and Chemieal Experiments, a book which tells how to perform hundreds of amusin? tricks in magic and instructire experiments with simpie

10. The Ilome Cook Book and Family Physi. clan, containiug hundreds of excellent cooking recipe's and hints to housekeeprrs, also telling

mon ailments by simple home remedy

11. Manners and Customs in Far A way Lauds, a very interesting and instructive book of travels. dexcrib ing the neculiar life. habits, manners and custons of the

12. Sixteen Complete Stories by Popnlar Authors, enibracing love, humorous and detective storics. stories teresting. 13. The Budget, of Wit, II umor and Fun, a large collection of the funny stories, sketches, anecdotes. Foen 14. Cseful Knomedre for the llillion, a ba: book of useful information for for the Million, a hatd

subjects: illustrated. A Norel, By Hugh Conwar, author

16. At the World's Merey. A Novel. By Florence Wardeu, author of ". The House on the Marsh," etc. 17. Mildred Trevanion., A tovel. By " The Duch ess," author of ". Mul.y Bawn," etc.

18. Durk Days. A Norel. By Hugh Conway, authos 19. Tled Myster.

19. The Mystery of the IIolly Tree. A Novel By the author of . Dora Thorne.

jo. Shadows on the snow. A Norel. By B. L. Far 21. The Gray Woman. A Norel. By Mrs. Gaskell, Barton," etc.

22. The Frozen Deep. A Norel. By Wilkie Collins. 23. Ked Court Farm. A Novel. By Mrs. Henry Wood, author of ."Fast Lynne," etc. 24. In Cupid's Net. A Novel. By the Author of "Dors Thorne."

25 . Baek to the old IIome. A Norel. By Mary Cecil.

Has, author of .. Hidden Perits.".

26. John Bowerbank's Wife. A Novel. By Miss 3iulock, author of 'John Halifax, Gentleman," ete. author of "Dora Thorue." etc.

:8. Janper Dane's Seeret. A Norel. By Miss M. E. I raddon, author of "Aurcra Flosd," ctc.
29 . Leoline. A Norel. By Nlary Cccil Hay, autlor of Brenda Yorke." etc.

30. Gabriel's Irarriage. A Norel. By Tilkic Collins,

31. David II unt. A Novel. By Mrs. Ann S. Stephens, anthor of " Fashion and Famine." ete.

3.. Kenplug the Whirlwind. A Norel. By Mary Cecil Har author of " Old Sirddetun's lioncy." cte. 33. Dudley Carleon. A Novel. By . Wiss M. L. Braddon, author of "Lady A udley's Secret, "ete.

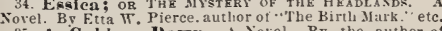
35. A Golden Dawn. A Novel. By the author of

36. Valerie's Fate. A Novel. By Nrs. Alexander, 3i. Sister Rose. A Norel. By Wilkie Collins, author of ".The Woman in White, "etc. Fast l,ynnc." A Norel. By Jirs. Henry Wood, anthor of 39 The Laurel Bush. A Norel. By Miss Mulock, author of "Juhn Halifax. Gentleman," etc. of "Adam Bede," "The Mill on the Floss," etc.

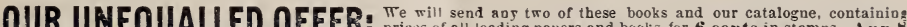
books 20 cts.: the whole 10 for 1.00. Send P. 1). Franklin News Co., Philad'a, Pa. 


\section{SUPERB LARCE NEW IMPERIAL GERMAN PANSIES
FLOWERRINC}

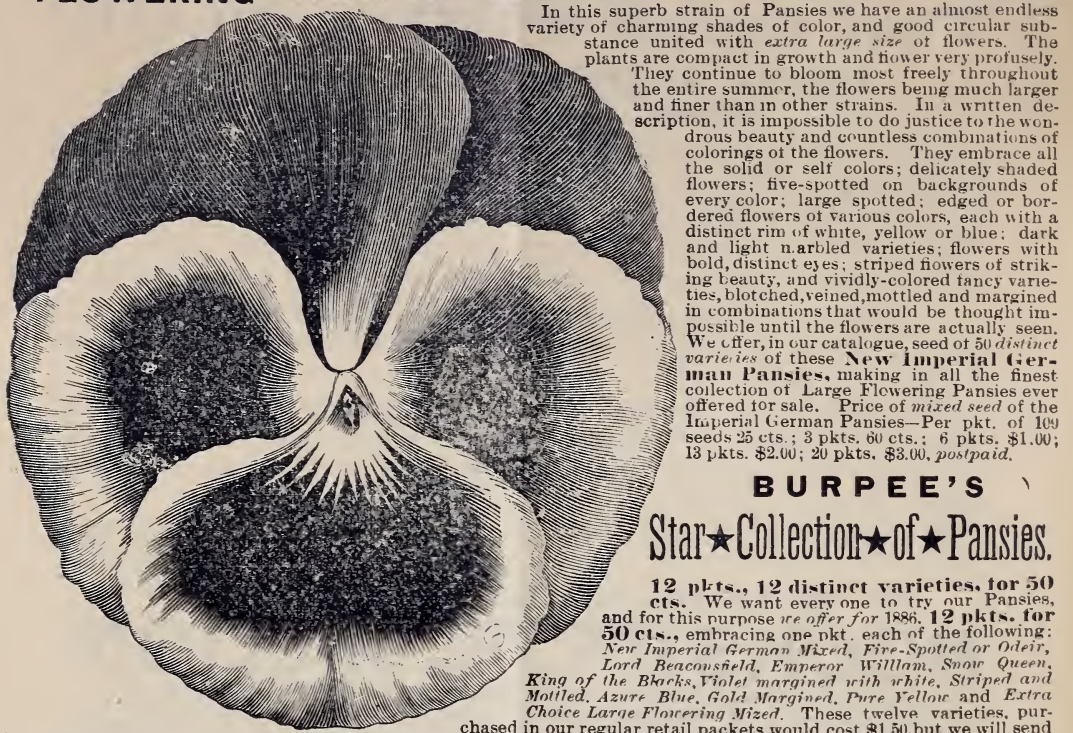

the entir collection postpaid, to any address on reciphased in our regular retail packets. have not already received a cony, ask for BU R PEE' F R VI A VUA TOR ISSG, with Imnerial German Pansies, and ilustrated descriptions of all the best Farden, Farm and Flower. Plants, $\& \mathrm{c}$. It is a handsome bonk of 128 pages, and is pronounced one of the best and inimt comnlete cataloger.

\section{W. ATLEe BURPEe \& CO.. Philadelphia, Pa.}

The "LITTLE GIANT"-with Flaring Body:

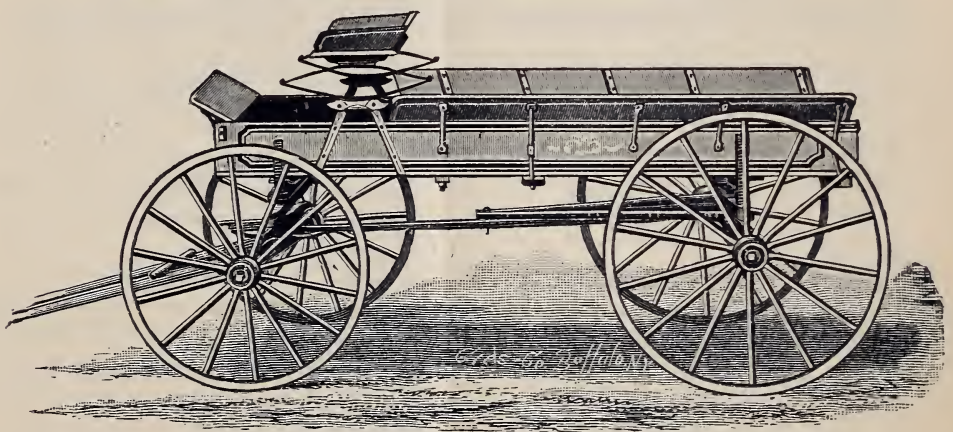

Having had numerous calls for a Wagon for drawing Trunkz, Garden Truck, \&c., we have added to our line the "Lit'le Giaut," with Flaring or Wing Body and Drop End Gate, ucder which we put the celebrated Duplex Bolster Springs.

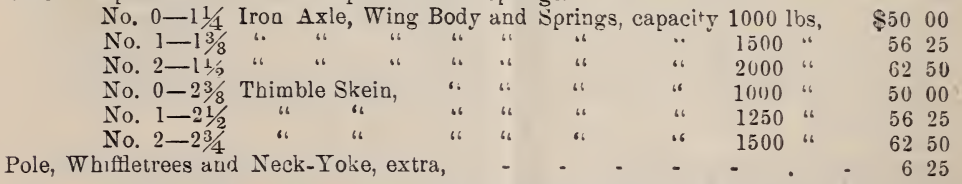

Subject to same l)iscounts as our regular "Little Giants," with Strait Boxes and Top Boxts. Send for full description of Two Horse Farm Wagons and Bob Sleighs. Every Wagon Warranted. Agents wanted where territory is not occupied.

E. D. CLAPP WAGON COMPANY, limited. Auburn N. Y. 


\section{CAYUGA LAND PLASTER。}

THE CHEAPEST FERTILIZER !-READ WHAT IS SAID OF IT !

"Plaster with the least $\epsilon$ xpense produces the beaviest crops." $-H$. Capen, laie $U$. S. Com'r Agricultnre.

"Gypsum is the saliva and gastric juice of plants."-Hedwig.

"Has fully proved one of the best and cheapest commercial fertilizers known to mankind." -II. Greeley.

"Fifty cts. worth gave increase of over 10 bushels wheat per acre.-U.S. Angel. Report 1872 , page 85.

- Have never known a poor farm on which plaster has been freely used - Levi Oberholtzer.

"C 4 uga Plaster contains an appreciableamount of phosphate of lime, which proportionately incruses its value.-Indiana Farmer.

"The result of a series of experiments in the use of Cayuga Plaster on Potatoes has been unexpectedl $\bar{y}$ favorable. In the most carefully conductea experiment increase was 33 per cerit."-Jolın J. Thomas.

Sold in car loads ouly. Send for Pr gressive Farmers' Memorandum Book-Free. CAYUGA PLASTER CO., Union Springs, N. Y

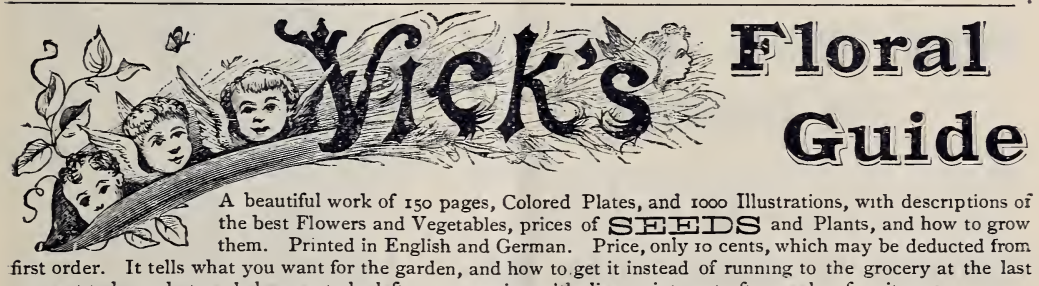
first order. It tells what you want for the garden, and how to. get it instead of running to the grocery at the last moment to buy what seeds happen to be left over, meeting with disappointment after weeks of waitıng.

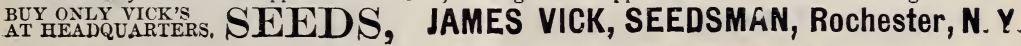

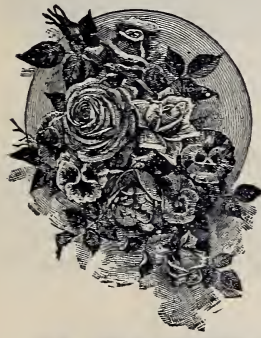
Vick's Illustrated Monthly Magazine.

This engraving represents the ELEGANT COLORED PLATE, $11 \frac{1}{2} \times 14 \frac{1}{2}$ inches, of ROSES AND PANSIES, which will be Given Away to cash subscribers to VICK'S ILLUSTRATED MONTHLY MAGAZINE, a beautiful publication, treating on every phase of gardening; 32 pages reading matter; colored plate, and many fine engravings each mouth. Price $\$ 1.25$ per year.

Any person sending four subscriptions with \$ุ๊.00, will receive Free a PORTFOLIO OF RARE AND BEAUTIFUL FLOWERS, consisting of Six Large Colored Plates, $11^{1} / 2 \times 11^{1} / 2$ inches, size and color true to nature, representing some of the rarest and most beautiful flowers in the world, and which, in their natural state, few persons will be apt to see. The Rose and Pansy Plate will be given to each member of the club. Price of Portfolio alone is $\$ 2.00$, and of the Rose and Pansy plate, 35 cents. Every one should possess a copy of this exquisite Portfolio. It is more than worth the effort.

JAMES VICK, SEEDSMAN, Rochester, N. Y.

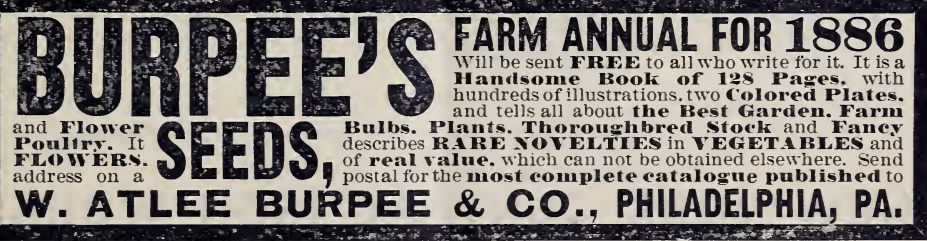

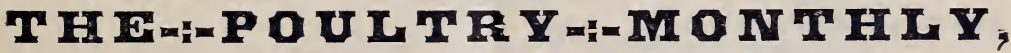

PUBIISFIDD AT AIBANY, N. $Y$.

IS THE LEADING MAGAZINE OF THIS COUNTRY.

Conducted by T, M. FERRIS,

Assisted by the most able corps,of contributors that can be procured for love or money. Its typographical appearance has been universally prononnced by the press evervwhere the finest of any Poultry Magazine pnblished in the English Language. IT STINDS TO-D. IT WI'THOCT A PEER. IN ENTIRE YEAR FOR $\$ 1.25$. Its advertising rates are upon a cash basis of ten cents per line. Address. FERRIS PUBLISHING CO., ALBANY, N. Y. 


\section{The DUNNING BOILER}

\section{PATENT, WROUGHT IRON OR STEEL.}

\section{With Self-Feeding Coal Magazine, is the Best and Oldest Low Pressure Steam Heater made.}

Insures a Warm House Day and Night.

Over 3,500 in Use.

Dampers Regullated and Coal Snp. plied Antomatically.

Requires much less Attention and much less Fuel than a Hot-Air Furnace.

Unexcelled for Heating Private Residences, Schools, Churches and Public Buildings.
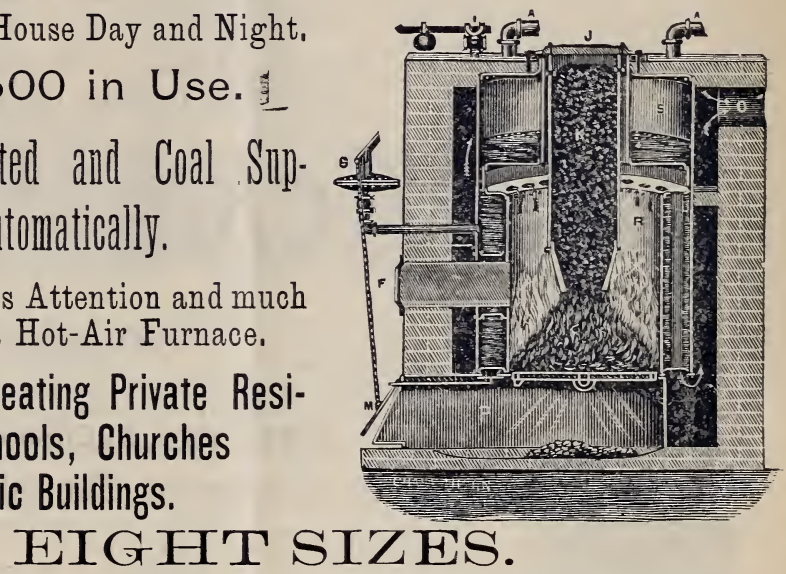

The larger sizes are specially adapted for heating churches, schcol houses, stores and buildings of the larger class.

Being made of one continuous sheet of best boiler iron or steel, it is not subject to the leakage incident to boilers constructed in cust-iron sections bolted togerher; or where the tubes come in contact with the fire unsupported.

Being self-feeding the heat is uniform throughout the entire 24 hours.

I also make a Surface Burning Boiler, to burn hard or soft coal,wood or coke.

I also make the Boilers in two sections in order to pass through any doorway.

Send for Illustrated Catalogue with full description and Price List.

N. B.-Correspondence solicited from architects and persons building.

MANUFACTURED AT THE

\section{NEW YORK CENTRAL IRON WORKS, GENEVA, N. Y.}

\section{REFERENCES :}

Dr. E. Lewis Sturtevant, Director of N. Y. State Agricultural Experiment Station, Genera, N. Y.

George F. Atwood, Nurseryman, Geneva, N. Y.

S. F. Terwilliger, Florist. Saratosa Spring

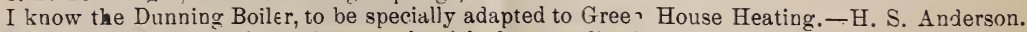
as Also numerous other references furnished on arplication. 
The Planet Jr. Horse Hoe, Cultivator Plow and Coverer Combined.

Except the handles this tool is mode entirely of wrought and analleable iron and steel; and has the standing clevis with locking pin, the stirrup clamp, the frame adj:1stable in width, the han tles cringeable in height, teeth adjustable to depth or angle, aud reversable points. Fur all crops that are hoed by hand it is invaluable. preceding the hand hoe, and saring three-fourtho of the work. Fo: all crops that are hilled. nothing can exceed three-fourths of the work, For all crops that are hilled, nothing can exceed
the perfection and ease with which this tool parform : the work, breaking up the soil perfectly and hilling the crop much or little as desired. As a cultivator it can be furnished with any width teeth from $1 \frac{1}{2}$ inch to $4 \frac{1}{2}$ inch, adapting it to every variety of soil. As an opening plow it is invaluable for making furrows for potatoes, corn and all uther crops as a c:verer it has no equal for corn. broom corn, potatoes, iu fact every

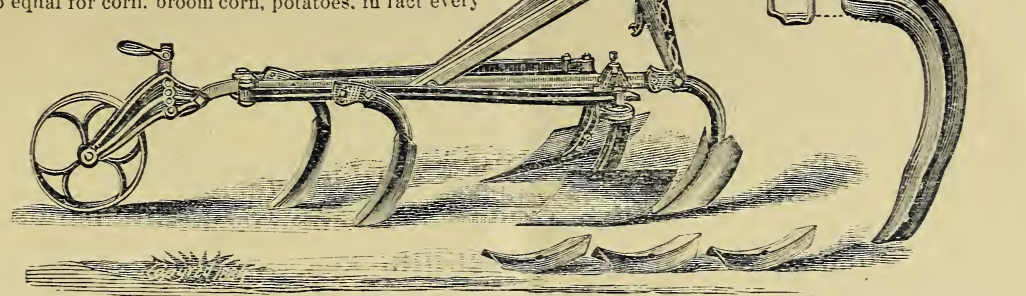

Find of corering, as it covers and rolls down the ground at one operation in ordinary fiejd work, or fits it for setting out plants or for using the garden sced drill, and whec! hoe. Price $\$ 9.00$ including wheel. Corering roller, $\$ 3.50$ extra. Extra set of cultivator points any width from $1 \frac{1}{4}$ to 4 inches, . .5 to $\$ 1.25$ per set

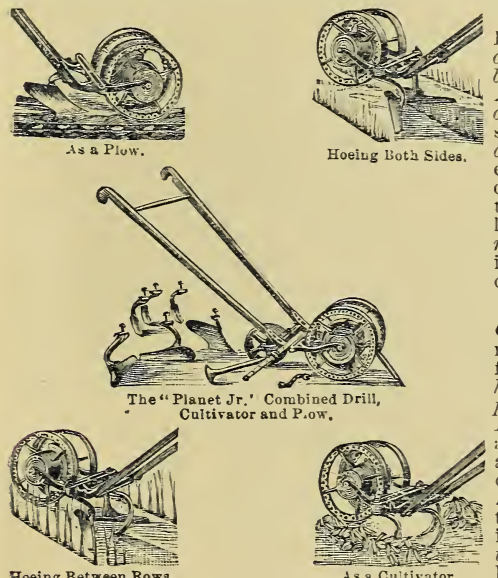

The Planet Jr. No. 2 Drill, Price 89.00 . Finlds $2 \frac{1}{2}$ qts It has the following important adrantages:-An Adjustable opening plou di ectly tetaten the carrying wheels. A spring brase rexerroir which can be accurately and instantly adjusted. An index for the sixteen most importint seeds cast permanently on tlie door. A good narker changeable from side to side instantly. A cleaner invaluable in aroiding rexatious clogging and burching of seed. With these advantages it will = ow with equal ease and accuracy. a single paper of seed or a full hopper, coverine evenly at any exact depth. and will roll down and mark the next row perfectly, all at a single passage. It has no.cams, levers, brushes, cogs. springs or shakers. It is noiseless. automatic, self-cleaning and always reliable. It is remarkable for its simpicity, strength and beauty, and for ease and perfection of work in the fie!d.

The Planet Jr. Combined Drill, Wheel Hoe, Wheel Cultivator and inheel Plow, Price \$11.00. This is the most popular macbine we hare ever sold. It is suitable either for the Farm or Garden, and except the Planet Jr. separate tools has no equal. either as a di ill. or as a wheel hoe culizirator and plow. It holds one quart. It has a finely adjustable Sming Brass seed Reservoir. an Adjustable Plow between the carrying and covering wheels, the new permanent Seed Index, the Cleaner a. d Marker all combining to make a perfect tool. As a plow it opens furrows, covers them, hills, plows to and from \&c., \&c. As a Hoe, it works safely and closely to and from both sides of the row at once, or between ro is as plants becomelarger, working all rows from 8 to 16 in. Wide at one passage. As a cultirator it is admirably adapted to deep mellowing of the soil. The blades are tempered and polished steel.

The Planet $J_{r}$, Double Wheel Hoe, Wheel Cultiva tor and Wheel Plow, Price s\%. Will do the work of from six to ten men with the common hand hoe among narket, gar den and root crops. nursery stock, \&c., and is especially adapted to onion culture. It is light, firm. strong, quickly set and easily, managed; each one is sent out with all the tools shown in the cut All the blades are tempered and polished steel. The hoes cut All the blades are tir cut from six to eighteen inches wide and can
to or from the row, workirig both sides at once.

The Planet Jr. Single Wheel Hoe, Plain, Price, s5. with set of three cultivator Teeth and Plow. price si. In improving this tool care has been taken to combine extreme lightness, strength, rariety of tonls and oreat adjustability. It bas one pair of long, and one pair of short exchangeable hoes, a set of three reversible cultivator teeth and a steel garden plow. s 11 the blades are tempered and polished steel. This tool is pronounced by practical men as withont an equal in beauty of design and finish, ease of operation, quality of work, and rariety of adjustment.

The Firefly Wheel Garden Plow, Price \$3. Makes the care of a regetable garden a pleasure. and 10,000 families who could not find time to keep a garden if attempting its cultivation with the ordinary hand hoe, can raise their own regetables successfully with the Firefly. It has a polished steel mold board and eyes for attaching a rope in plowing double depth in the spring. It opens furrows for peas, beans, corn, potatoes,
$\& c$, and neatly covers them. The tool cun be quickly adjusted $\& \mathrm{c}$, and neatly covers ther

Delivered at depot in Philadelphia, packed for shipment at prices named.

prices named. implements fail to write for Descriptive Catalogie of these $\mathrm{Hoei}_{\mathrm{g}}$ Between Rows.

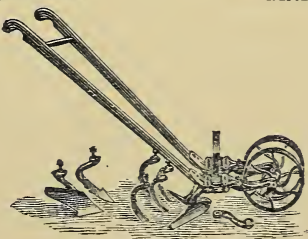

The "Planet Jr." Doub'e Theel Hoe, Cultivator and $\mathrm{Ylow}$.

Address, H. S ANDERSON, Cayuya Lake Nurseries, Unicn Springs. N. Y. 


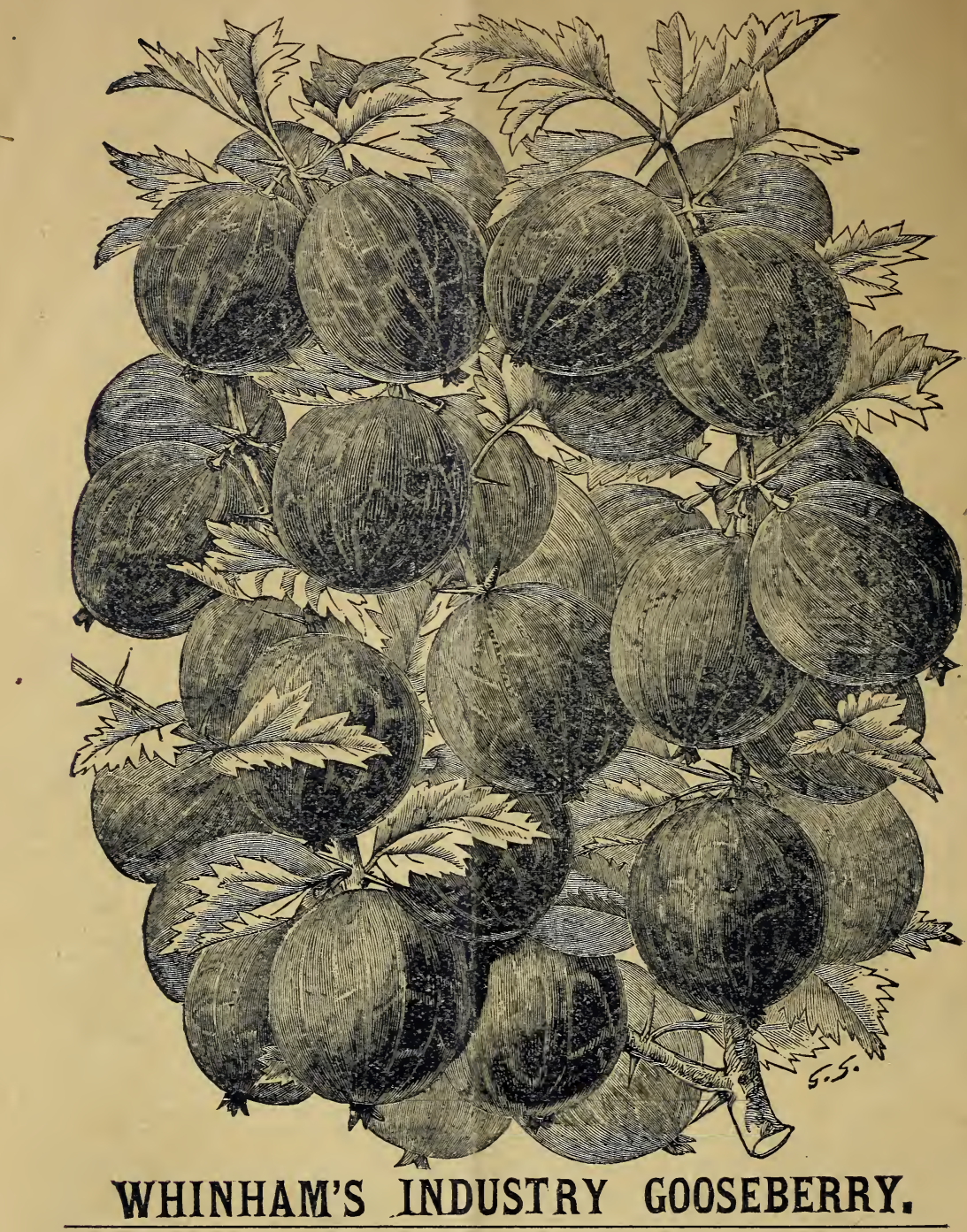

TW STIMTOIVIATS.

Sifelberne, Vt.: " The box of plants came last night and I must candidly admit that they are the best plants and more thoroughly packed than any I have ever received. I am greatly p'eased with them."

GReensboro, Md.: "I received the plants $(9,0,0)$ in good order and am much pleased with your promptness in filling the order."

Bergen Point, N. Y.: " "Grapevines received in good order."

MEAdTille, Pa: "I received the Marlboros ye terday, and had them a!l set in i. less than an hour. * * * I am well pleased with them."

Rove, Ill : "Niag ara vine received all right. am well pleased with it.."

Motwi Hol.Ly, N. J.: "The Marlboro plants received all right, good strong p'ants, much pleased with them."

STERLING, Kans.: "Springfield rasberry plants received and in good order and full number."

JACKSONTILLE, Fla: "Grapevines re:eivzd and in good condition, well rcoted and I think will do well, am well pleased in every particular."

SALT LAKE City, UTAH: "Grapevines to hand in good condition, am well p'eased with care in packing," \&c.

SMIth's GRove, Ky.: " Niagara vine reached me in good condition." 